\title{
MERCANTILIZAÇÃO DA LINGUAGEM NA PROMOÇÃO DO TURISMO DE LUXO NA SELVA IRYAPÚ (MISIONES, ARGENTINA): AUTENTICIDADE, DESLOCAMENTOS E RESISTÊNCIA
}

\author{
LANGUAGE COMMODIFICATION IN LUXURY TOURISM PROMOTION \\ IN THE IRYAPÚ JUNGLE (MISIONES, ARGENTINA): \\ AUTHENTICITY, MOBILITIES AND RESISTANCE
}

Simone da Costa Carvalho*

\begin{abstract}
RESUMO
Vivendo na região da tríplice fronteira Argentina-Brasil-Paraguai, comunidades indígenas da cidade argentina de Puerto Iguazú têm sofrido modificações sociais e territoriais devidas a políticas que resultaram na construção da área turística Selva Iryapú, explorada por redes hoteleiras nacionais e internacionais. Este artigo discute os usos da linguagem na promoção do turismo nessa área, onde elementos da língua e da cultura guaranis são mobilizados para produzir autenticidade e gerar valor agregado simbólico (HELLER; DUCHÊNE, 2012, 2016). Para elaborar este estudo de caso de caráter exploratório, foi realizada pesquisa bibliográfica sobre os guaranis e o turismo na tríplice fronteira; posteriormente, foram efetuadas seleção e análise de textos utilizados na promoção do turismo na área. A análise aponta que tanto os hotéis de luxo quanto as comunidades indígenas mobilizam recursos da língua e da cultura guaranis para gerar valor agregado a produtos e serviços turísticos. No caso dos guaranis, tais usos expressam tanto adesão ao enquadre de lucro quanto estratégias de resistência, de uso desses discursos em prol da preservação de sua língua e cultura. Embora diversos estudos da área apontem a mercantilização da linguagem como possível potencializadora da agentividade dos sujeitos e de geração de renda a grupos minoritários, no presente caso argumentamos que os guaranis, inseridos em uma relação de exploração e alienação capitalista com o empreendimento Selva Iryapú, posicionam-se entre a necessidade e a resistência.

Palavras-chave: sociolinguística e turismo; mercantilização da linguagem; autenticidade.
\end{abstract}

\begin{abstract}
Living in the Triple border Argentina-Brazil-Paraguay region, Argentine city Puerto Iguazú’s Indigenous communities have undergone social and territorial changes due to policies that have resulted in the construction of the Iryapú Jungle tourist area, exploited by national and international hotel networks. This paper aims to discuss the language uses in tourism promotion within this area, where Guarani language and culture elements are mobilized to produce authenticity and generate symbolic added value (HELLER; DUCHÊNE, 2012, 2016). To elaborate this exploratory case study, bibliographic research on the Guaranis and tourism in the Triple border was initially carried out; subsequently, regional tourism promotion texts were selected and analyzed. The analysis points out that both luxury hotels and Indigenous communities mobilize Guarani language and culture resources to generate added value to tourism products and services. In the Guarani's case, these uses express both adherence to the profit framework and resistance strategies, using these discourses in favor of their language and culture preservation. Although several studies in the area point to language commodification as a possible promoter of the subjects' agency and the income generation to minority groups, we argue that the Guaranis, inserted in a capitalist exploitation and alienation relation with the Iryapú Jungle enterprise, are in a position between necessity and resistance.

Keywords: sociolinguistics and tourism; language commodification; authenticity.
\end{abstract}

\section{INTRODUÇÃO}

As atividades turísticas se expandiram e passaram a envolver um grande fluxo de capitais internacionais, inserindo-se nas dinâmicas do chamado capitalismo tardio a partir principalmente dos anos 1990 (HELLER; McELHINNY, 2017). O turismo representa hoje uma das maiores indústrias internacionais do mundo ${ }^{1}$ e tornou-se central na formulação de políticas públicas, econômicas, sociais e culturais que visam ao crescimento econômico de países tanto centrais quanto periféricos, como ocorre na região da tríplice fronteira Argentina-Brasil-Paraguai. Nessa região localizam-se as Cataratas do Iguaçu, consideradas em 2012 uma das sete maravilhas do mundo², o que

* Universidade Federal da Integração Latino-Americana (UNILA), Foz do Iguaçu, PR, Brasil. simonecc@hotmail.com Orcid: https://orcid.org/0000-0002-9408-3630

1. Este estudo de caso analisa período anterior à pandemia do novo coronavírus, iniciada em 2020, que levou à suspenção das atividades turísticas em praticamente todo o mundo, alterando essa condição.

2. Disponível em: <http://g1.globo.com/pr/parana/noticia/2012/05/cataratas-do-iguacu-e-consagrada-uma-das-sete-maravilhas-da-natureza. html>. Acesso em 28 mai. 2021. 
contribuiu para o processo de massificação do turismo no local. As Cataratas estão protegidas por dois parques, o Parque Nacional Iguazú (Argentina) e o Parque Nacional do Iguaçu (Brasil), declarados Patrimônio Natural da Humanidade pela UNESCO em 1992, região em que estão inscritos respectivamente os territórios da cidade argentina Puerto Iguazú e da cidade brasileira Foz do Iguaçu. Em 2019, o Parque Nacional argentino recebeu cerca de 1.635.237 visitantes, enquanto o Parque Nacional do Iguaçu, do lado brasileiro, bateu o recorde de 2.020.358 visitantes ${ }^{3}$.

Vivendo próximas ao Parque Nacional Iguazú, no município de Puerto Iguazú (na província argentina de Misiones), comunidades indígenas mbiá-guaranis ${ }^{4}$ passaram a sofrer, a partir de 2003, modificações sociais e em seu espaço geográfico devido a políticas de turismo que resultaram na construção da Selva Iryapú ou 600 bectares, área fortemente dominada por redes hoteleiras nacionais e internacionais.

Neste artigo analisamos alguns usos da linguagem para a promoção do turismo nessa área, com o objetivo de discutir como elementos da língua e da cultura guaranis são mobilizados, tanto pela rede hoteleira de luxo quanto pelas comunidades indígenas locais, para produzir autenticidade e gerar valor agregado simbólico (HELLER; DUCHÊNE, 2016). Nos baseamos na discussão proposta por Heller e Duchêne $(2012,2016)$ de que recursos semióticos considerados autênticos estão cada vez mais sendo mobilizados em atividades econômicas que criam nichos de mercado ou agregam valor a produtos e serviços, e de que os discursos de orgulbo estão cada vez mais interligados a discursos de lucro.

De base qualitativa (MASON, 2002) e caráter exploratório, este estudo de caso (GIL, 2008) foi realizado em duas etapas: primeiramente foi feita pesquisa bibliográfica de estudos anteriores sobre os guaranis e sobre o turismo na região da tríplice fronteira (DIECKOW, 2012; CANTORE; BOFFELLI, 2017; ENRIZ, 2011 e 2018; GONZÁLES et al., 2017; HERNÁNDEZ, 2017; MELIÀ, 2008 e 2016; WILDE, 2007), articulada posteriormente à discussão dos usos de linguagem em foco. Em um segundo momento, foi efetuada pesquisa e seleção de textos turísticos de distintas fontes (veiculados em cartazes, anúncios publicitários, textos publicados em blogs de viagem, em redes sociais e em portais digitais de hotéis da área turística) envolvendo o uso de recursos da língua e da cultura guaranis na promoção do turismo na Selva Iryapú. Para fins de análise, foram examinados usos de elementos da língua e cultura guaranis para gerar valor agregado a produtos e serviços turísticos e seu cruzamento com processos de construção da autenticidade através dos critérios de bistoricidade, lugar, produtos e pessoas (PIETIKÄINEN et al., 2016).

Em estudos da linguagem envolvendo comunidades falantes de línguas minorizadas em espaços turísticos (PIETIKÄINEN et al., 2016; JAFFE, 2019; PIETIKÄINEN; KELLY-HOLMES, 2011; KELLY-HOLMES; PIETIKÄINEN, 2014), sinaliza-se que a abertura para a mercantilização da autenticidade e das línguas-culturas tem criado espaços para a ocorrência de processos agentivos protagonizados pelos sujeitos das comunidades envolvidas com relação a suas línguas e identidades, bem como trazido oportunidades de geração de renda em nível local. O presente artigo visa contribuir com o campo das discussões sobre mercantilização da linguagem na exploração turística em áreas periféricas contrapondo-se aos achados dos citados estudos, argumentando que, no caso aqui abordado, longe de tratar-se de um processo de mercantilização da autenticidade que se origina pelas demandas dos sujeitos e potencializa sua agentividade, o que se observa é o desenvolvimento de um projeto de exploração capitalista que posiciona os mbiá-guaranis entre a necessidade e a resistência.

$\mathrm{O}$ artigo organiza-se do seguinte modo. A segunda seção expõe os entendimentos teóricos iniciais sobre capitalismo tardio e mercantilização da linguagem, pano de fundo para o contexto em foco. A terceira apresenta brevemente o âmbito do turismo em Puerto Iguazú e a configuração territorial dos mbiá-guaranis na Selva Iryapú. A quarta seção explicita os entendimentos teóricos sobre autenticidade e discute alguns processos de mercantilização da autenticidade protagonizados pelos hotéis de luxo e comunidades indígenas na Selva Iryapú. Por fim, as considerações finais sugerem alguns aprofundamentos deste estudo.

3. Disponível em: <http://www.aen.pr.gov.br/modules/noticias/article.php? storyid=105231\&tit=Parque-Nacional-do-Iguacu-bate-recordede-visitantes-em-2019>. Acesso em 28 mai. 2021.

4. Com relação à nomeação desse povo indígena, optamos pela grafia mbiá-guarani ou mbiá, em consonância com as ideias de Fiorin e Petter (2008, p. 10). 


\section{SOCIOLINGUÍSTICA CRÍTICA: CAPITALISMO TARDIO, MERCANTILIZAÇÃO DA LINGUAGEM E OS DISCURSOS DE ORGULHO E LUCRO NO TURISMO}

Como uma das maiores atividades econômicas mundiais, o turismo tornou-se um domínio importante para investigar os complexos aspectos de produção de significados na modernidade tardia. Heller, Pujolar e Duchêne (2014) destacam que o turismo constitui espaço-chave para a exploração sociolinguística da economia política da globalização, especialmente em periferias multilíngues. Ao traçar um panorama de três fases do capitalismo (capitalismo inicial, de bem-estar social e tardio), mostram como a concepção de linguagem foi sofrendo modificações, além de relacioná-la às atividades turísticas.

O capitalismo inicial (industrial) caracterizou-se, por um lado, pela dominação econômica, e, por outro, pela emancipação política e constituição de vários Estados-nação na Europa e na América durante os séculos XVIII e XIX. Um aspecto central dos Estados-nação foi a constituição de mercados nacionais por meio da padronização e homogeneização da linguagem e da cultura e da participação da população em diferentes instituições nacionais. A mobilização de sentimentos de orgulho e pertencimento são essenciais para o engajamento na causa comum do Estado-nação: "ser um cidadão orgulhoso de um país, ou membro da nação, e tratar seus símbolos (bandeira, língua, literatura e mapa) com respeito são dimensões essenciais de viver as versões de Estado-nação daquilo a que Bourdieu (1972) se referia como "habitus'"5 (HELLER; DUCHÊNE, 2012, p. 5). Os discursos alinhados a esses entendimentos são identificados pelos autores como discursos de orgulho. Do ponto de vista da Sociolinguística, o discurso e a concepção dominante de linguagem como um sistema fechado e com limites claros, interligados com identidade e território, são centrais para a legitimação do Estado-nação enquanto modo de regulação do capital (HELLER; DUCHÊNE, 2012).

Após a Segunda Guerra Mundial, o turismo de elite abriu caminho ao turismo de massas, que foi tornado possível pelo capitalismo de bem-estar social, pela emergência de uma ampla classe média nos países centrais e pelas novas relações de trabalho em que as férias trabalhistas passaram a ser uma regra. Nos anos 1980, convergindo com o ápice do capitalismo industrial e do Estado de bem-estar, a expansão do capitalismo levou à terceirização, ao neoliberalismo e à nova economia globalizada, caracterizada principalmente pela acumulação flexível e pelo crescimento do capitalismo financeiro (HARVEY, 2016). Quando os lucros diminuem por conta da saturação dos mercados, o modo especulativo tende a surgir, levando à extensão e à intensificação, pelo engajamento das empresas: na procura de novos mercados para seus produtos; na venda de produtos por preços mais baixos que os de seus competidores; na criação de novos tipos de consumidores, necessidades e desejos; na especialização em produtos para mercados de nicho; na justificativa de preços mais altos através de valor agregado aos produtos (HELLER; McELHINNY, 2017, p. 3). Esses processos juntos desestabilizam a habilidade do Estado-nação, típica do capitalismo industrial, de regular os mercados, ou seja, a capacidade de regular a produção e a circulação de produtos e serviços, bem como seus produtores e consumidores (HELLER; DUCHÊNE, 2012).

Nessa etapa, denominada capitalismo tardio, as empresas passam a mover sua produção industrial aos países periféricos, ao mesmo tempo em que ocorre a retirada, pelos Estados-nação, das proteções do Estado de bem-estar, o que desmonta a base econômica anteriormente construída sobre a cidadania nacional. A iminência do capitalismo tardio trouxe também transformações sociolinguísticas, já que desloca as questões de linguagem e identidade para a lógica de produção e consumismo cultural, inserindo-as no que Heller e Duchêne (2012) denominam discursos de lucro. É nesse contexto que surge o conceito de mercantilização, "para descrever como um objeto ou processo específico é tornado disponível para uma troca convencional no mercado" (HELLER; PUJOLAR; DUCHÊNE, 2014, p. 545).

Assim, a partir dos anos 1990, pudemos testemunhar como a nova economia globalizada e as políticas neoliberais afetaram os valores de base do Estado-nação. Em diversos Estados, o fechamento de fábricas e a modificação dos modos de produção levaram muitos governos a redefinir políticas nas quais o turismo emergiu como atividade econômica que mobiliza a identidade local como recurso ou como forma de valor agregado (HELLER; PUJOLAR; DUCHÊNE, 2014, p. 546). A partir disso, um aspecto recorrente na

5. Todas as traduções de citações diretas de textos escritos em inglês ou espanhol são de responsabilidade da autora. 
literatura sobre turismo e sobre o desenvolvimento de economias comunitárias tem sido o valor situado da autenticidade (HELLER, 2005), que confere um caráter de distinção a objetos e experiências culturais mercantilizados.

A partir desses entendimentos, o presente trabalho pauta-se na ideia de que, na contemporaneidade, por conta da mudança nos modos de produção gerados pela nova economia globalizada, muitos atores sociais passaram a mobilizar culturas e identidades locais como recursos ou como forma de agregar valor a outros produtos, no processo aqui denominado mercantilização. Nesse sentido, a autenticidade passa a ser um importante elemento que agrega valor a produtos e serviços (HELLER, 2005). Como afirmam Heller e Duchêne (2012), os discursos de lucro não interrompem ou substituem os discursos de orgulho; eles não apenas convivem, mas se entrelaçam de maneiras complexas, resultando em tensões e contradições, amplamente manifestas em áreas como o turismo, onde a linguagem como fonte de orgulho e identidade é também mobilizada para a obtenção de lucro, mais frequentemente na forma de turismo cultural.

\section{TURISMO E TERRITÓRIO EM PUERTO IGUAZÚ E O CONTEXTO MBIÁ-GUARANI NA SELVA IRYAPÚ}

Nesta seção apresentamos o contexto territorial e turístico onde se insere a Selva Iryapú. Inicialmente enfatizamos a relação entre o turismo e a segregação do espaço na cidade de Puerto Iguazú e, a seguir, destacamos como a perda de territórios e a exploração turística afetam a subsistência e os modos de viver dos mbiá-guaranis nessa região.

\subsection{Turismo e segregação do espaço em Puerto Iguazú}

A estrutura hoteleira de Puerto Iguazú foi fortemente atingida nos anos 1990 pelos ciclos econômicos de depressão turística ocasionados pelas mudanças financeiras relacionadas às oscilações do dólar. A falta de investimento público e privado tem levado à deterioração do capital social da cidade, em um processo de construção de soluções paliativas (DIECKOW, 2012). O município de 42.849 habitantes $^{6}$ (censo de 2010) sofre desde sua criação com problemas de infraestrutura e oferta de serviços públicos para a população, situação que se associa à baixa capacidade orçamentária para resolver problemas estruturais, dando à gestão pouco poder de negociação diante dos grupos de investidores, em geral estrangeiros (DIECKOW, 2012, p. 172).

Apresentado em 2003 com o objetivo de desenvolver o turismo na província de Misiones, o projeto 600 bectares, Selva Iryapú, tencionava ampliar a oferta hoteleira e estruturas de lazer em Puerto Iguazú. O empreendimento contou com território cedido pelo Parque Nacional de Iguazú à província de Misiones, ficando a planificação e a gestão sob responsabilidade do governo provincial. Sua execução reposicionou as Cataratas do Iguaçu dentro dos mercados turísticos internacionais, atraindo grandes investidores financeiros. As políticas turísticas da província excluíram a comunidade das instâncias de discussão do projeto, o que gerou descontentamento nos investidores provinciais. Após tensões e negociações, foram incluídos alguns empresários locais nas discussões e compactuaram-se possíveis benefícios do empreendimento para o turismo local (DIECKOW, 2012).

Conflitos territoriais marcaram também a participação das comunidades guaranis estabelecidas nesse território, ameaçadas pela exploração turística dos hotéis. Tais terras eram historicamente de uso tradicional indígena, sendo que a primeira escola para crianças indígenas nessa área foi fundada em 1982 (ENRIZ, 2018). O território foi objeto de batalha judicial e, após conflito legal, a lei 4098/04 concedeu à comunidade guarani 265 hectares dos 600 hectares da área do projeto. Os 300 hectares restantes foram cedidos em concessão ou venda para cadeias hoteleiras, e avançou a construção de grandes estabelecimentos na Selva Iryapú, planejados para uma população de classe socioeconômica alta. Em 2012, havia na área 24 hotéis de cadeias hoteleiras como Hilton, Hyatt, Radisson, Panamericano, Loi Suites e Tekoa, com um investimento estimado de 150 milhões de dólares (DIECKOW, 2012).

Na Figura 1, a seguir, vemos um mapa da Selva Iryapú, com a seguinte distribuição: Zona 1 (25\% da área), composta de área social, cultural, esportiva e de recreação; Zona 2 (10\%), destinada a hotéis de 3 a 4 estrelas; Zona $3(10 \%)$, hotéis de 4 e 5 estrelas, com acesso exclusivo ao rio Iguaçu; Zona 4 (10\%), planejada para atividades

6. Dados do Instituto Provincial de Estatísticas y Censos (IPEC, 2010). Disponível em: < https://ipecmisiones.org/wp-content/uploads/2019/04/ IPEC-Misiones-1-Poblaci\%C3\%B3n-por-sexo-seg\%C3\%BAn-municipio-Censo-2010.pdf>. Acesso em 28 mai. 2021. 
ecoturísticas e campo de golf; Zona 5 (45\% do território), representando a Reserva Natural e Cultural mbiá-guarani, com superfície de 265 hectares.

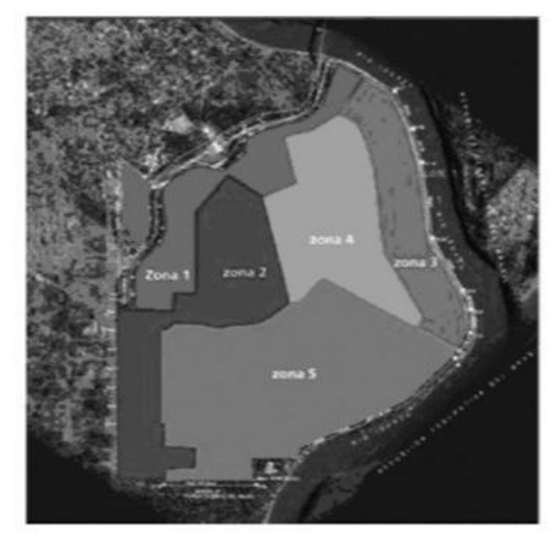

Figura 1: Mapa das zonas da Selva Iryapú

Fonte: DIECKOW, 2012, p. 174.

O projeto anunciava investimentos na cidade e ações que respondessem às demandas locais. No entanto, trazia implícito, desde o início, a separação de espaços turísticos dos não turísticos, criando um processo de segregação social e espacial marcado pela construção de áreas diferenciadas e de empreendimentos com acesso exclusivo ao rio Iguaçu (GONZÁLES et al., 2017). Além disso, essa política turística e territorial impactou de maneira significativa a comunidade mbiá-guarani, afetando seus meios de vida e subsistência.

\subsection{Economia política e território: os modos de vida mbiá-guaranis e os contrastes na Selva Iryapú}

Segundo a publicação Guarani Retã (MELIÀ, 2008), vivem na região da fronteira Argentina-Brasil-Paraguai cerca de 100.000 indígenas do povo guarani, distribuídos nos três países em aproximadamente 500 aldeias e comunidades. Em Misiones, segundo o Instituto Provincial de Estatísticas y Censos (2010)7, vivem mais de 13.000 mbiáguaranis, distribuídos em 120 tekoá, ou comunidades (MELIÀ, 2016).

Os mbiá-guaranis são conhecidos desde o século XVIII como moradores dafloresta, termo inicialmente usado pelos jesuítas para designar esses indígenas que fugiam da evangelização e dos povoados religiosos, refugiando-se na mata (WILDE, 2007). Apesar das interações progressivas com práticas hegemônicas, até cerca de quatro décadas atrás os mbiás da Argentina conseguiam manter-se historicamente afastados da sociedade dominante, ao sustentar-se dos recursos das áreas habitadas. Entretanto, a progressiva destruição de seus territórios criou uma situação econômica crítica para esse povo, ameaçando sua subsistência.

Atualmente, a economia de Misiones se organiza principalmente pela produção industrial de erva-mate e derivados, bem como por atividades vinculadas ao turismo, à extração de madeira e à plantação de espécies florestais. Os interesses de capital privado têm exercido forte pressão sobre o território, afetando pequenos produtores e também a população indígena (CANTORE; BOFFELLI, 2017, p. 54).

O território é um eixo fundamental para a compreensão do modo de ser e viver do povo mbiá-guarani, que vê seu mundo como uma região de matas, campos e rios, espaço onde vivem segundo seu modo de ser e sua cultura milenar (MELIÀ, 2008).

São males, para os Guarani, uma terra esgotada para a agricultura, uma paisagem desértica, um campo sem árvores ou, na atualidade, a produção de gado e as monoculturas da soja, pinus ou cana de açúcar, que ameaçam suas vidas e seus territórios. (MELIÀ, 2016, p. 10 , grifo do autor)

Vivendo em aldeias e comunidades pequenas, os mbiás buscam manter seu modo de vida próprio, sua organização social (ver Figura 2), sua religião e sua língua. No entanto, a pressão de empresas e organismos sobre os territórios é uma realidade em toda a província, alterando o modo de vida desse povo.

7. Disponível em: <https://ipecmisiones.org/wp-content/uploads/2019/04/IPEC-Misiones-20-Poblaci\%C3\%B3n-ind\%C3\%ADgena-o-descendientepor-sexo-seg\%C3\%BAn-edad-en-a\%C3\%B1os-simples-o-grupos-quinquenales-de-edad-Censo-2010.pdf>. Acesso em 28 mai. 2021. 

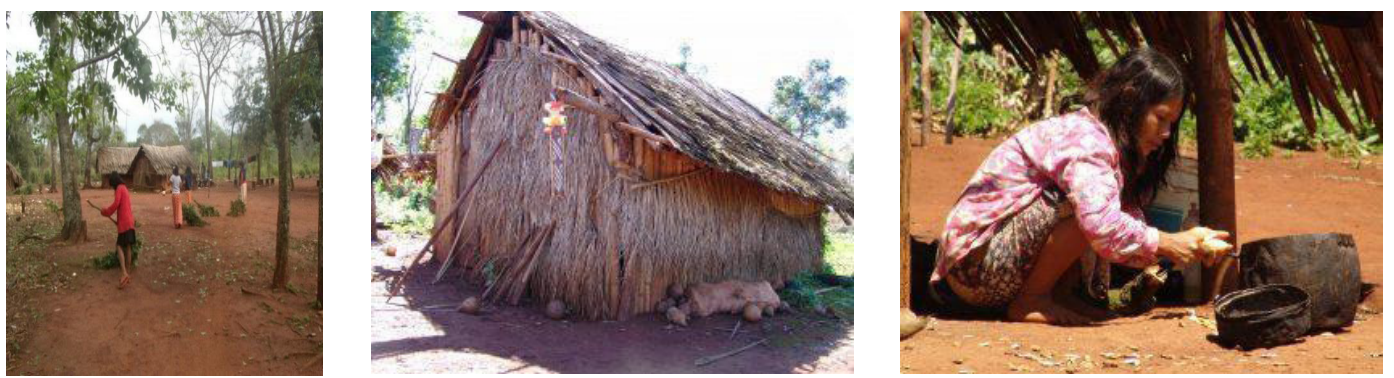

Figura 2: Comunidades indígenas mbiá-guaranis na Selva Iryapú

Fonte: Proyecto Mate, $2021^{8}$.

O empreendimento 600 bectares diminuiu à metade os territórios habitados pelas comunidades indígenas nessa área, atingindo diretamente sua organização territorial. Sem o reconhecimento estatal, com a crescente destruição da floresta e dificuldade de acesso à terra, a situação econômica tornou-se crítica, pondo em risco a subsistência das comunidades, levando à necessidade irremediável de fazer contato com a sociedade dominante e à dependência do dinheiro. A confecção de artesanato para os turistas não é suficiente. Logo, a diminuição de sua capacidade de autogestão aumentou o poder de organizações assistencialistas, que passaram a intervir nos assuntos internos das comunidades (WILDE, 2007, p. 378).

A construção da área turística reconfigurou também a territorialidade local: ao adentrar a Selva Iryapú, o que chama a atenção inicialmente são os significados contrastantes que compõem a paisagem: uma área natural onde compartilham espaço quatro aldeias mbiá-guaranis e vários hotéis de luxo. A Figura 3, a seguir, retrata a infraestrutura de um dos hotéis e o evidente contraste com as comunidades locais, mostrando a vista aérea do empreendimento, o saguão de entrada e a área externa com piscina.
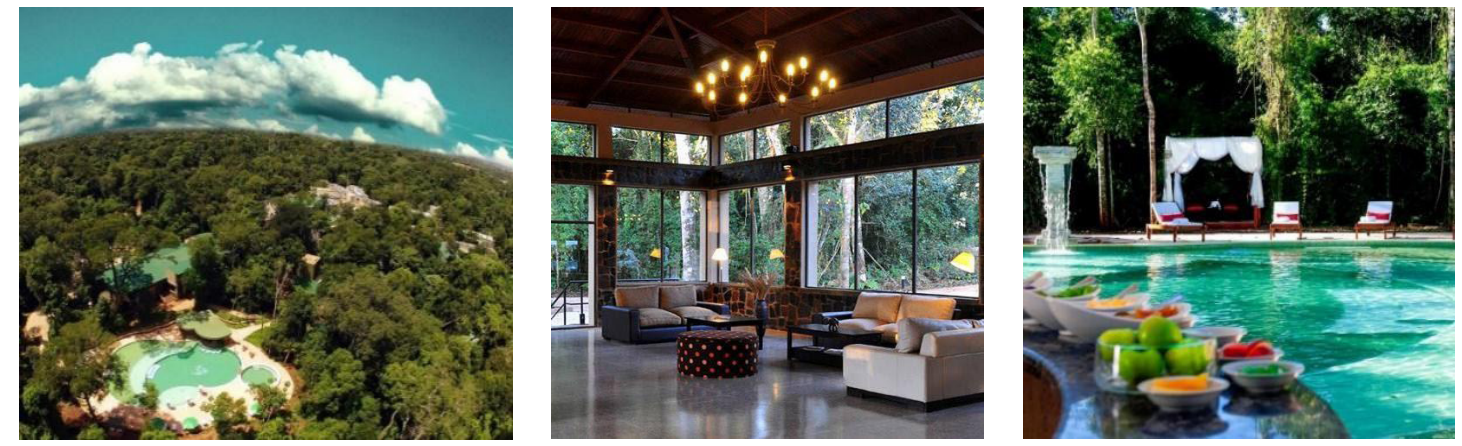

Figura 3: Fotos de Ivy Hotel de Selva

Fonte: TripAdvisor, $2021^{9}$.

Como afirmam Gonzáles et al. (2017, p. 376), é "paradoxal o nível de sofisticação dos empreendimentos de capital transnacional ao expressar certos padrões tecnológicos e urbanos em função de uma ideia de marca e de um estilo de vida próprio dos países de origem do capital". Resulta que a relação entre os turistas que se hospedam nos 600 bectares e o entorno da cidade é geralmente restrita a visitas programadas, que de preferência evitem o contato com a população local.

\section{MERCANTILIZAÇÃO DA AUTENTICIDADE ENVOLVENDO A LÍNGUA E A CULTURA MBIÁ-GUARANIS NA SELVA IRYAPÚ}

Nesta seção discutimos alguns processos de mercantilização da autenticidade protagonizados tanto pelos hotéis quanto pelas comunidades indígenas na Selva Iryapú. Apresentamos, inicialmente, os entendimentos teóricos

8. Imagens disponíveis em: <http://proyectomate.org/galeria-multimedia/>. Acesso em 28 mai. 2021.

9. Disponível em: <https://www.tripadvisor.com.br/Hotel_Review-g312806-d4584369-Reviews-Yvy_Hotel_de_Selva-Puerto_Iguazu_ Province_of_Misiones_Litoral.html>. Acesso em 28 mai. $202 \overline{1}$. 
sobre a mercantilização da autenticidade, com destaque para as noções de desvio e enclave. Em seguida, analisamos como, através do uso da linguagem, o setor hoteleiro de luxo da Selva Iryapú mobiliza o imaginário guarani para gerar lucro e valor agregado a seus produtos. Concluímos a seção discutindo de que maneiras as comunidades indígenas, pressionadas pela ocupação de seus territórios e diante das demandas de subsistência impostas, passaram a ressignificar sua cultura e identidade como produtos do mercado turístico, bem como a utilizá-los como espaços de resistência e preservação.

\subsection{Mercantilização da autenticidade: discussão do conceito}

O capitalismo tardio e seus processos de crescente mercantilização têm trazido novas possibilidades e circunstâncias para as chamadas línguas pequenas (PIETIKÄINEN et al., 2016). Como vimos, devido à saturação dos mercados, empresas e produtos tendem cada vez mais a criar nichos para poder distinguir-se da concorrência. Ocorre que as línguas pequenas, por sua própria condição, oferecem essa distinção, sendo cada vez mais utilizadas para autenticar aspectos materiais e imateriais de um produto.

As noções de desvio e enclave, descritas por Appadurai (1986) e articuladas por Pietikäinen et al. (2016), ilustram os processos envolvidos na mercantilização das línguas e culturas. As línguas pequenas, especialmente quando não são mais faladas ou porque seus falantes estão em risco, tendem a ser objeto de proteção, em geral em nome de determinados grupos, criando enclaves, "rotas culturalmente convencionadas para o fluxo das coisas" (APPADURAI, 1986, p. 42). Paradoxalmente, essa mesma proteção, por conta do caráter raro e exótico que confere à linguagem, cria condições para a mercantilização da própria linguagem através de processos que Appadurai (1986) denomina desvios. Os desvios envolvem tirar a linguagem da sua "rota culturalmente convencionada", e "são sempre um sinal de criatividade ou crise, seja estética ou econômica" (APPADURAI, 1986, p. 42). Na modernidade tardia, percebe-se cada vez mais a ocorrência de desvios das línguas pequenas, deslocadas da sua posição inicial como locais e veiculares para serem revestidas de novos valores, seja como objetos de troca elas mesmas, seja como meio de potencializar outros produtos.

No centro desses processos encontram-se as ações de autenticação, que criam as condições para que ocorra o desvio de linguagem de uma rota culturalmente convencionada em direção à mercantilização. Nos espaços vistos como periféricos e inseridos nas mudanças econômicas globais, a autenticidade é altamente demandada, sendo muito usada como critério de avaliação e valoração de pessoas, práticas, lugares e produtos (PIETIKÄINEN et al., 2016). O turismo cultural baseia-se na premissa de que o turista vai ter contato com elementos culturais autênticos dos lugares que visitar. No entanto, o entendimento e a construção do que é autenticidade vêm sofrendo modificações. Enquanto a perspectiva convencional de autenticidade invoca a ideia do falante nativo de uma língua minoritária pura em um contexto tradicional, novas percepções desse processo são agora mais situadas e conectadas à mudança. Os valores ligados à autenticidade estão sempre em movimento e sob constante negociação, processos que não ocorrem sem tensões ou restrições, e com consequências para as relações envolvendo linguagem e cultura (PIETIKÄINEN et al., 2016, p. 104).

Nos processos de autenticação do turismo cultural ou de experiência, como os apresentados neste texto, seguem sendo elementos essenciais: a bistoricidade (continuidade de um passado, transmissão de uma tradição através do tempo), o lugar (os limites geográficos determinados, o caráter remoto do local, sua distinção de centros imaginados ou reais, o caráter de lugar vazio), os produtos (autenticados por sua origem local, seu caráter exótico) e as pessoas (a identidade como modo de autenticação, o uso de roupas, nomes, usos da linguagem, performances) (PIETIKÄINEN et al., 2016).

Neste trabalho, nosso foco sociolinguístico está na seleção e no uso de recursos linguísticos e semióticos nas ações que visam produzir valor agregado simbólico a produtos e serviços turísticos, tanto pela rede hoteleira de luxo instalada na Selva Iryapú quanto pelas comunidades indígenas que habitam esse território. Alinhados a Pietikäinen et al. (2016), observamos os papéis que a bistoricidade (tempo), o lugar, os produtos e as pessoas desempenham nos processos de autenticação e de mercantilização da autenticidade analisados nesse contexto.

\subsection{Mercantilização do outro: o uso do imaginário guarani na promoção do turismo pelo setor hoteleiro de luxo na Selva Iryapú}

O projeto 600 bectares, desde seu princípio, foi promovido como de desenvolvimento turístico, imobiliário e ecológico em plena selva virgem. Discursos que remetem ao exotismo da região e ao imaginário mbiá-guarani são 
característica fundamental do marketing de turismo na Selva Iryapú. Destacamos aqui dois processos observados: a mobilização de elementos da língua e da cultura guaranis para construir valor agregado simbólico e a mercantilização do outro, indígena que habita esse território, nos discursos de promoção do turismo de luxo pelo setor privado. Embora os hotéis da área sejam de três, quatro e cinco estrelas, ou seja, destinados a públicos-alvo de extratos econômico-sociais variados, os dados aqui analisados correspondem mais especificamente ao chamado "turismo de luxo" (THURLOW; JAWORSKI, 2012), voltado a um consumidor de nicho altamente privilegiado economicamente, cuja distinção é associar o apelo ecológico ao consumo de luxo em suas viagens.

Uma das condições para que a propaganda do turismo cultural seja bem-sucedida é a construção do imaginário turístico, no qual a linguagem verbal e multimodal desempenha um papel central. Segundo Hernández (2017, p. 74, grifos do autor), "a 'experiência turística' é, inicialmente, uma geografia imaginada por um potencial consumidor de destinos turísticos", em um processo alimentado por imagens, relatos, sons descritos por diferentes atores com o objetivo de despertar interesse em determinado local. Estudos na área da Sociolinguística do turismo têm explicitado processos de midiatização e mercantilização do outro (HELLER; JAWORSKI; THURLOW, 2014) mobilizados para a construção dessa geografia imaginada.

No caso aqui abordado, há duas figuras de linguagem da autenticidade promovidas no turismo: a promoção da natureza inexplorada e a oferta das origens (presentes em estudos sobre turismo cultural e de herança, como em KellyHolmes e Pietikäinen, 2014) da cultura mbiá-guarani. O local é descrito em portais virtuais de turismo e pelos hotéis da região como um paraíso intocado, onde o turista pode "perder-se na profundidade da selva missioneira e desconectar-se da rotina e do estresse ${ }^{\prime \prime 10}$, sentindo-se distante da agitação urbana e em harmonia com a natureza exuberante. Essa experiência se tornaria possível pelo contato com a flora e a fauna da região, e visitas às comunidades originárias que permitiriam o contato com o modo de vida do povo mbiá-guarani, que, segundo as representações construídas, vive em perfeita comunhão com a natureza. De acordo com texto do portal digital do Ministério de Turismo de Misiones, "os mbiá-guaranis são um antigo povo de selva de raízes amazônicas. Sua cultura é tão rica como a biodiversidade da selva paranaense onde têm vivido e que protegeram desde sempre". ${ }^{11}$

Como exemplo de mobilização desse imaginário, destacamos alguns textos do portal digital de um dos empreendimentos mais luxuosos da Selva Iryapú, o Awasi Iguazú Hotel ${ }^{12}{ }^{13}$, cujo material de propaganda apresenta uma profusão de elementos semióticos que promovem a ideia da selva inalterada e do imaginário guarani. A página conta com sofisticadas produções audiovisuais, bem como ilustrações de pássaros e exemplares da fauna e flora do parque nacional, acompanhados de áudios com cantos de diferentes espécies de pássaros da região. Em um dos vídeos promocionais, denominado The Land Without Evil (A terra sem mal) ${ }^{14}$, o discurso do imaginário guarani é utilizado e esteticamente narrado com vários elementos visuais indígenas e da selva, exibidos como parte da experiência a ser comprada e vivida pelo hóspede desse hotel. O vídeo, narrado em off em língua guarani por um indígena local, que também é protagonista do audiovisual, possui legendas em inglês com o seguinte texto:

The jungle is part of our life and wisdom: just as we are a part of the jungle. Our grandparents taught us that if a particular species of bird goes missing, then one of the strings within the web of nature bas broken. We believe that when sometbing is missing in the ecosystem, people are born filled with anxiety. Children are the most connected to nature. We would like to show Awasi guests that there still exists a community in this world where people protect their grandparents, shelter their children and work around the sun to preserve their environment: in our case the jungle. We bope that the Guarani community and Awasi can share the same path. (...) (Fragmentos da narração do vídeo The Land Without Evil) ${ }^{15}$

Enquanto se ouve a voz do narrador em guarani, imagens da floresta, de uma onça, de outras espécies da fauna são apresentadas, tendo ao fundo o som da música mbiá-guarani. Outras cenas mostram imagens do narrador caminhando pela floresta, de crianças indígenas em contato com a natureza e de um coro indígena cantando e tocando instrumentos guaranis. Todos os elementos remetem à sabedoria originária, à ideia de proteção da natureza e das

10. Trecho de um texto de divulgação do Hotel Loi Suites. Disponível em: <https://loisuites.com.ar/es/hotel/loi-suites-iguaz\%C3\%BAhotel>. Acesso em 28 mai. 2021.

11. Disponível em: <http://www.misiones.tur.ar/es/pueblos-originarios/> . Acesso em 28 mai. 2021.

12.Disponível em <https://awasiguazu.com/about/?gclid=EAlaIQobChMIoPSb1svE5QIVIYKRCh3aGwjdEAAYASAAEgLTp_D_BwE>. Acesso em 28 mai. 2021.

13. Neste hotel, o valor mínimo da diária é de $\$ 900,00$ dólares americanos por pessoa.

14. Vídeo disponível em: <https://vimeo.com/showcase/4915412/video/254848246>. Acesso em 28 mai. 2021.

15. A selva é parte da nossa vida e sabedoria, assim como nós somos parte da floresta. Nossos avós nos ensinaram que se uma espécie particular de pássaro desaparece, então um dos fios da teia da natureza se rompe. Nós acreditamos que, quando alguma coisa desaparece do ecossistema, as pessoas nascem cheias de ansiedade. As crianças são as mais conectadas à natureza. Nós gostaríamos de mostrar aos hóspedes do Awasi que ainda existe uma comunidade nesse mundo onde as pessoas protegem seus avós, abrigam suas crianças e trabalham em torno do sol para preservar seu ambiente: em nosso caso, a floresta. Nós esperamos que a comunidade guarani e do Awasi possam compartilhar o mesmo caminho. 
espécies, de convivência harmoniosa com a floresta, explorados também no título do vídeo, ao referir a Terra sem mal ${ }^{16}$ dos guaranis, compondo um conjunto de elementos semióticos que convidam os hóspedes do hotel a compartilhar a experiência de contato e equilíbrio com a natureza representados no vídeo. $\mathrm{O}$ narrador do audiovisual é um indígena que vive em uma das comunidades da região, do mesmo modo que as crianças e o coro apresentados nas imagens, presenças que conferem maior autenticidade ao que o Awasi Hotel busca vender aos seus hóspedes.

Nos textos apresentados observa-se uma explícita apropriação pelos hotéis do imaginário guarani, utilizandose como fontes de autenticação (PIETIKÄINEN et al., 2016) a bistoricidade (o "antigo povo de selva de raízes amazônicas", a cultura dos antepassados citada no vídeo, corroborando a continuidade do passado guarani), o lugar (o caráter remoto e distinto do local, que permite "desconectar-se da rotina e do estresse"; a rica "biodiversidade da selva paranaense onde [os guaranis] têm vivido e que protegem desde sempre", "a terra sem mal") e, no caso do vídeo promocional, as pessoas (a própria imagem dos indígenas que habitam a região como forma de autenticação, imagens das crianças e do coro na floresta, o discurso em off gravado em guarani). Tais processos de autenticação são fundamentais na construção da distinção e no processo de mercantilização de representações da língua e da cultura guaranis pelos hotéis na Selva Iryapú.

Uma das problemáticas apontadas é que a construção desse imaginário pelo setor hoteleiro envolve o apagamento explícito das reais condições de vida e de organização social e cultural do povo mbiá-guarani que habita a região, havendo uma higienização e um recorte daquilo que é projetado e que interessa ao desenho do produto turístico de luxo. Tal representação, disfarçada de uma suposta valorização da cultura originária, tem servido para invisibilizar ainda mais a situação do povo guarani que vive não só na cidade de Puerto Iguazú, mas em toda a província de Misiones.

Outra modalidade de consumo da autenticidade é a oferta de objetos autênticos, como bebidas, comidas, souvenirs e artigos de artesanato (PIETIKÄINEN et al., 2016), cujo valor autêntico pode ser intensificado se forem apresentados em linguagem autêntica ou como parte de uma atividade ou marca. Na Figura 4, vemos uma foto do portal digital do empreendimento anteriormente citado, cujo objetivo é promover a gastronomia de luxo do hotel. Na imagem, vê-se uma típica peça de artesanato indígena mbiá-guarani local, nesse caso a escultura de um jacaré talhado em madeira, adornando a mesa de jantar e sugerindo a possibilidade de pratos típicos e exóticos.

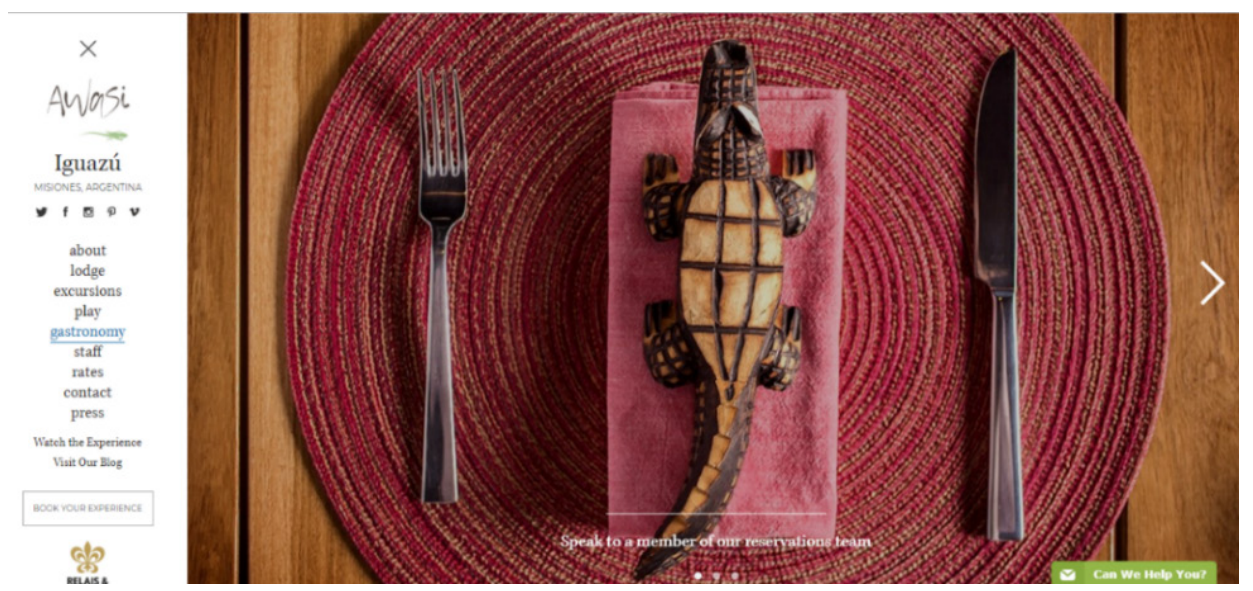

Figura 4: Fotografia de portal digital de um hotel da Selva Iryapú

Fonte: Portal digital do Awasi Iguazú Hotel, $2021^{17}$.

Vemos a articulação do autêntico, materializada em uma peça de produção artesanal indígena, como um elemento que confere maior valor agregado ao produto turístico, à experiência cultural de estar fazendo uma refeição nesse hotel específico, localizado em plena selva, próximo da cultura originária na Selva Iryapú. Ou seja, essa escultura é apropriada pelo empreendimento e deslocada de seu contexto original de produção, para agregar valor a uma marca, ou atividade comercial, nesse caso, culinária e turística. Tal deslocamento corresponde a um desvio de um elemento de linguagem da sua rota convencional de origem, e à transição de um registro mundano a um registro de luxo: uma "restrição, quer por preço quer por lei, a elites; complexidade de aquisição que pode ou não

16. A Terra sem mal corresponde a um espaço mítico que diz respeito ao modo de viver guarani, e consequentemente à economia e subsistência desse povo (MELIÀ, 1989). Consiste na busca por terras boas e sanas que permitam ao seu povo subsistir harmoniosamente baseado em seu modo de viver, sendo o motivo fundamental do nomadismo guarani.

17.Disponível em: < https://awasiguazu.com/pt/gastronomia/>. Acesso em 28 mai. 2021. 
ser uma função de 'escassez' real" (APPADURAI, 1986, p. 57). Segundo Thurlow e Jaworski (2012), os aspectos visuais e corporificados em objetos nas paisagens semióticas do turismo de luxo representam a ideologia dos grupos de elite e funcionam para produzir distinção de classe. Desse modo, observa-se a mercantilização dos recursos locais (materialidades associadas a percepções da língua e da cultura guaranis) que há alguns anos não tinham valor de mercado e que agora, diante de uma nova configuração econômica global, são apropriados para produzir distinção, tornando as experiências ofertadas produtos turísticos únicos, voltados a grupos sociais de elite. Tais características inserem o caso em tela no que poderíamos chamar turismo de experiência de luxo.

Do ponto de vista das relações do capital (HARVEY, 2016), identificamos vários aspectos de projetos capitalistas da área do turismo: desvios de linguagem e da cultura locais; uso do aparato de publicidade massiva; apropriação de territórios de alto valor turístico e financeiro com o aval do Estado, dentre outros. Ademais, destacam-se de modo pungente o desequilíbrio econômico no acesso e uso de recursos para a promoção do turismo, bem como dos ganhos obtidos a partir dele. As empresas possuem uma vantagem econômica desproporcional ao apropriar-se da imagem do indígena, tendo a seu serviço um forte aparato publicitário que sustenta o turismo de escala global, construindo-se, assim, uma relação desigual entre hotéis e comunidades locais.

Encontramos nessa relação forte ressonância do conceito marxista de alienação (HARVEY, 2016, p. 268; 2018 , p. 428). No conceito original de Marx, a alienação situa-se no plano da produção: o trabalhador é alienado do processo do trabalho; ele produz a mercadoria, mas não possui nenhum poder sobre o que produz ou nenhum direito sobre o valor que advém desse produto. O valor pertence ao capital, bem como o próprio produto. Posteriormente, na obra Grundrisse, Marx (1857 apud HARVEY, 2018, p. 425) atribui um sentido mais subjetivo ao conceito: se nos tornamos separados do que nos pertence e perdemos o controle sobre isso, nos alienamos disso. Harvey (2018) discute e amplia essa dimensão subjetiva, relacionando-a aos três planos de circulação do capital: produção, realização e distribuição. O autor destaca que, com o advento do capitalismo tardio, a alienação deslocou-se em grande parte do âmbito da produção, para o da realização (venda de produtos e serviços; terceiro setor) (HARVEY, 2016, p. 270; 2018, p. 433).

No caso em exame, o sentido do conceito de alienação remete, primeiramente, à despossessão daquilo que é produzido simbolicamente pelas comunidades guaranis locais, no caso, os elementos linguísticos e culturais gerados por eles, articulados à sua revelia, pelos empreendimentos turísticos de luxo na produção de um imaginário guarani distante da realidade e da identidade dos próprios sujeitos indígenas; em segundo lugar, diz respeito à privação do acesso pelas comunidades guaranis à riqueza que é criada a partir desses elementos, ou seja, do lucro gerado a partir da mercantilização de produtos e serviços turísticos de luxo cuja autenticidade é sustentada pela existência das próprias comunidades indígenas no local.

Em resumo, o uso da historicidade, de elementos da língua e do artesanato guaranis pelos hotéis consiste em uma apropriação de recursos de linguagem ligados à cultura e à tradição desse povo originário, produzidos pelas próprias comunidades como discursos orientados ao enquadre de orgulho. A mercantilização dessas fontes de autenticação no mercado turístico insere tais atividades nos discursos de lucro típicos do setor turístico e de outras atividades desenvolvidas no âmbito da nova economia. Tal apropriação remete também a questões de legitimação e de economia política, já que os empreendimentos estão aptos não apenas a realizar essa comercialização do outro, mas de receber todos os lucros que provêm desse comércio, em detrimento das próprias comunidades mbiá-guaranis, alienadas da representação inventada de sua própria cultura e dos ganhos que se geram a partir dela.

A seguir apresentamos alguns usos da linguagem e recursos semióticos que apontam para a mercantilização de elementos da cultura guarani pelas próprias comunidades da área em questão.

\subsection{Mercantilização de recursos da língua e da cultura guaranis pelas comunidades indígenas: entre a necessidade e a resistência}

Forçados pela nova economia globalizada, os mbiá-guaranis foram levados a adaptar-se ao turismo na Selva Iryapú, em um processo de ressignificar sua própria cultura e identidade como objetos do mercado turístico. Assim, a mercantilização de experiências envolvendo percepções da cultura guarani também é protagonizada pelas comunidades originárias que habitam a área, por meio, principalmente, de visitas guiadas nas aldeias, passeios por senderos e venda de artesanato nas aldeias locais e postos de turismo na cidade. 
Como vimos anteriormente, a autenticidade confere valor a experiências mercantilizadas como sendo algo cultural ou natural, e tem sido amplamente explorada no turismo cultural em atividades cujo valor autêntico é intensificado por serem apresentadas em linguagem vinculada às pessoas que as vivenciam ou desempenham como parte de sua própria cultura (PIETIKÄINEN et al., 2016, p. 94). Explora-se como principal fonte de autenticação as pessoas das próprias comunidades, sua cultura e sua linguagem.

No caso dos guaranis de Misiones, com a crescente invasão e perda de territórios, a venda de artesanato passou a ser importante na economia de subsistência de muitas comunidades (CANTORE; BOFFELLI, 2017). Em Puerto Iguazú, artigos de artesanato mbiá-guarani são comercializados no parque nacional, nas ruas da cidade e nas comunidades (ver Figura 5). Nas aldeias da Selva Iryapú são vendidas principalmente figuras de animais talhados em madeira, cestos de fibras vegetais, colares e pulseiras confeccionados com sementes, dentre outros objetos, como arcos e flechas.

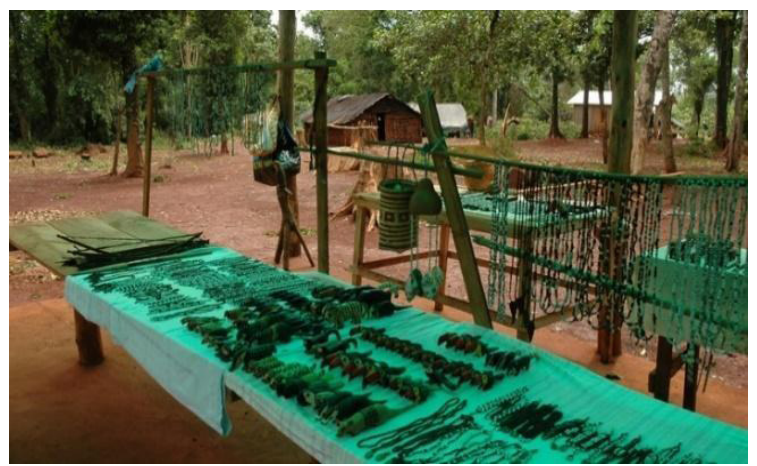

Figura 5: Tenda de artesanato em comunidade mbiá-guarani na Selva Iryapú

Fonte: Portal digital Welcome Argentina, $2021^{18}$.

Além da venda de artesanato, o principal produto turístico ofertado pelos mbiás na Selva Iryapú são as visitas guiadas por indígenas das comunidades locais (ver Figura 6). Nessas visitas, a/o turista pode testemunhar como vivem os mbiá-guaranis da comunidade, suas casas, plantações, comidas típicas, bem como ter acesso a relatos de sua história ancestral. Em uma das comunidades, modalidades de visita mais longa incluem uma caminhada pela floresta para reconhecimento de ervas medicinais utilizadas pelos mbiás e conhecer armadilhas para a caça de animais. Ao final do passeio, a/o turista tem oportunidade de comer comidas indígenas feitas à base de milho ou mandioca e assistir à performance de um coro guarani. Os coros são compostos majoritariamente por crianças e jovens, que cantam em guarani e tocam alguns instrumentos tradicionais, sendo geralmente conduzidos por um adulto, que toca um instrumento de base, normalmente o violão. Ao final do percorrido, a/o turista é conduzida/o a uma tenda na qual são vendidas peças típicas de artesanato confeccionado pelos mbiá-guaranis.
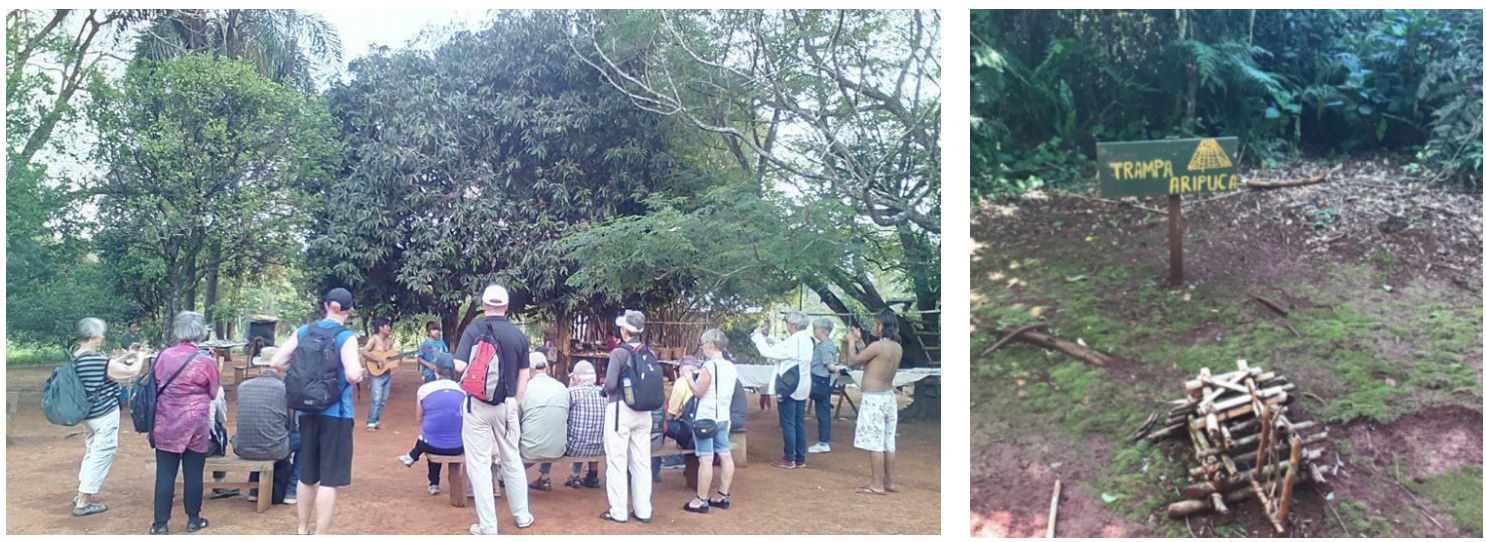

Figura 6: 1) Visita guiada em comunidade local e 2) Armadilha para animais Fonte: Rede social Facebook, $2021^{19}$.

18. Disponível em: <https://www.welcomeargentina.com/puertoiguazu/aldea-jasy-pora.html >. Acesso em 28 mai. 2021.

19.Disponíveis em: <https://www.facebook.com/turismoguaraniYryapu/photos/?ref=page_internal >. Acesso em 28 mai. 2021. 
Alguns aspectos chamam a atenção nesses eventos, já que a maior parte das famílias das comunidades locais não vivem mais do que plantam, nem a caça é uma atividade de subsistência ou prática corrente na reserva (WILDE, 2007; ENRIZ, 2018). Na maioria dos casos, pela falta de territórios suficientes à sua subsistência, os guaranis passaram a consumir alimentos industrializados provindos da cidade, comprados com a baixa renda obtida da venda de artesanato e por meio de subsídios estatais (ENRIZ, 2011). Ocorre também durante as visitas o deslocamento de rituais do seu contexto original para o evento turístico, como é o caso do coro guarani constituído para fins de turismo (ver Figura 7), cujo papel tradicional está ligado à religião mbiá-guarani, em rituais sagrados privados, e que aqui aparecem ressignificados para o contexto turístico (CANTORE; BOFFELLI, 2017). Observa-se nisso o que Kelly-Holmes e Pietikäinen (2014, p. 523) denominam autenticidade encenada, a busca por reproduzir ou recriar práticas que, todavia, não são mais correntes ou originais naquela cultura, deslocando-as de seu contexto original, com o objetivo de satisfazer supostas expectativas de turistas por um encontro autêntico com a cultura local (ENRIZ, 2018). Tensões acerca desses desvios (APPADURAI, 1986) são geradas, pois as práticas de turismo e mercantilização de elementos relacionados à cultura mbiá e seus desdobramentos não são aprovadas por todos os membros das comunidades $^{20}$ (CANTORE; BOFFELLI, 2017). Como apontam Heller, Jaworski e Thurlow (2014, p. 426), os processos de mercantilização produzem "uma tensão entre o desejo de capitalizar e produzir em massa nossa língua, culturas e identidades, por seu caráter único e exótico, enquanto alimenta-se a necessidade de reter (ou reclamar) sua autenticidade, propriedade e legitimidade".
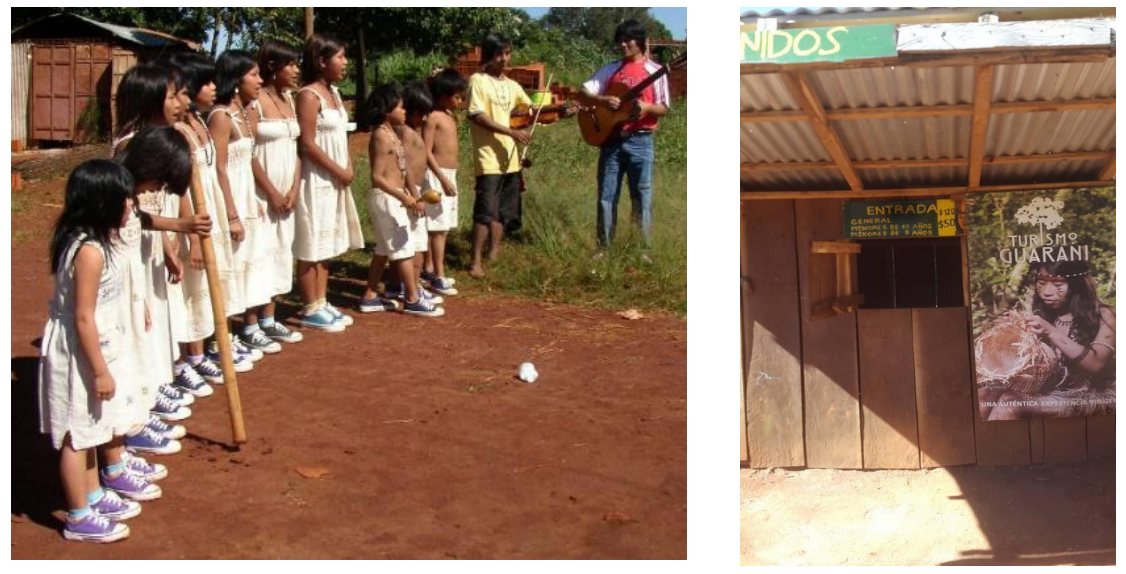

Figura 7: 1) Coro guarani; 2) Guichê de ingressos em comunidade local Fontes: Proyecto Mate e Facebook, $2021^{21} 22$.

No entanto, ainda que, por um lado, o turismo como campo da economia globalizada imponha o enquadre discursivo de lucro, por outro lado, também pode figurar como espaço de "negociação e contestação acerca do acesso, do protagonismo e da mercantilização de recursos linguísticos e culturais indígenas" (KELLY-HOLMES, PIETIKÄINEN, 2014, p. 522). Na selva Iryapú, embora as comunidades locais tenham pouco capital político de mobilização quando comparadas aos empreendimentos privados, podemos observar algumas estratégias discursivas, respostas que vão sendo construídas localmente, e que interpretamos como ações de resistência. Dentre elas, destacamos a reconfiguração dos coros guaranis para eventos turísticos e o mapa Nuestro Territorio Ore Rekoa.

No caso dos coros de crianças e jovens guaranis, cuja performance é deslocada de seu contexto religioso e privado tradicional para figurar como atração turística, Cantore e Boffelli (2017) destacam as estratégias utilizadas pelos sujeitos no processo de reposicionar aspectos de sua cultura quando o público-alvo é o turístico. Nesse caso, a configuração apresentada ao turista não é a mesma utilizada nos rituais:

[a]parecem mudanças vinculadas à composição musical, à interação entre os participantes, às danças que acompanham os cantos, às letras das canções e os espaços onde se realizam as performances. Uma diferença importante são os termos linguísticos que se utilizam para referir-se aos cantos e danças de um e outro contexto (Dallanhol, 2002; Boffelli, 2017). No que se refere às letras, se bem que

20.Cantore e Boffelli (2017), Wilde (2007) e Enriz (2010) problematizam a complexa relação das comunidades originárias com agentes externos, como ONGs, agentes de turismo e governo argentino, que derivam das práticas de crescente mercantilização e turismo. Neste texto, por limitação de espaço, não abordaremos esse tema.

21.Disponível em: <http://proyectomate.org/wp-content/uploads/2018/06/Coro.jpg > . Acesso em 28 mai. 2021.

22. Disponível em: <https://www.facebook.com/turismoguaraniYryapu/photos/1809732082581126>. Acesso em 28 mai. 2021. 
encontramos temáticas comuns (como o canto a suas deidades e ao vínculo com a floresta ou temáticas mítico-cosmológicas), diferem em sua composição. (CANTORE; BOFFELLI, 2017, p. 59, grifo das autoras)

As autoras consideram essas adaptações como parte das estratégias adotadas pelos mbiá-guaranis para preservar práticas sagradas e tentar apropriar-se a seu modo do processo de mercantilização turística. Pietikäinen et al. (2016) destacam que, além das tensões que emergem desses processos e práticas multilíngues complexos, atos e ações criativos são importantes para lidar com esses conflitos nos contextos das línguas pequenas. No caso dos coros guaranis, para além da mercantilização, entendemos esses atos de criatividade como atos de resistência: a retextualização e a reinscrição de antigos discursos sobre linguagem, comunidade e identidade que são realinhados (PIETIKÄINEN et al., 2016, p. 116) para preservar a identidade e a cultura locais. Essa apropriação dos discursos também pode ser compreendida como letramento de reexistência (SOUZA, 2011), conceito construído com base nas lutas e resistências da comunidade negra no Brasil. Letramentos de reexistência envolvem uma reinvenção de práticas e usos sociais da linguagem que os sujeitos realizam a partir de suas experiências de vida e do cotidiano, para provocar "releituras de identidades étnicas, de gênero, sexualidade, políticas, dentre outras" (SOUZA et al., 2018, p. 2). Desde essa perspectiva, os sujeitos são agentes de letramento que se apropriam da linguagem para se colocarem como protagonistas de sua história e de suas próprias narrativas.

Outro exemplo de contraponto aos discursos de lucro e que identificamos com os letramentos de reexistência é o mapa Nuestro Territorio Ore Rekoa, instalado em um painel na entrada da Selva Iryapú em maio de $2017^{23}$ (ver Figura 8). Nele as comunidades indígenas protagonizam discursos sobre a identidade e a luta política do povo mbiá, bem como explicitam um posicionamento mais agentivo acerca do turismo na área.

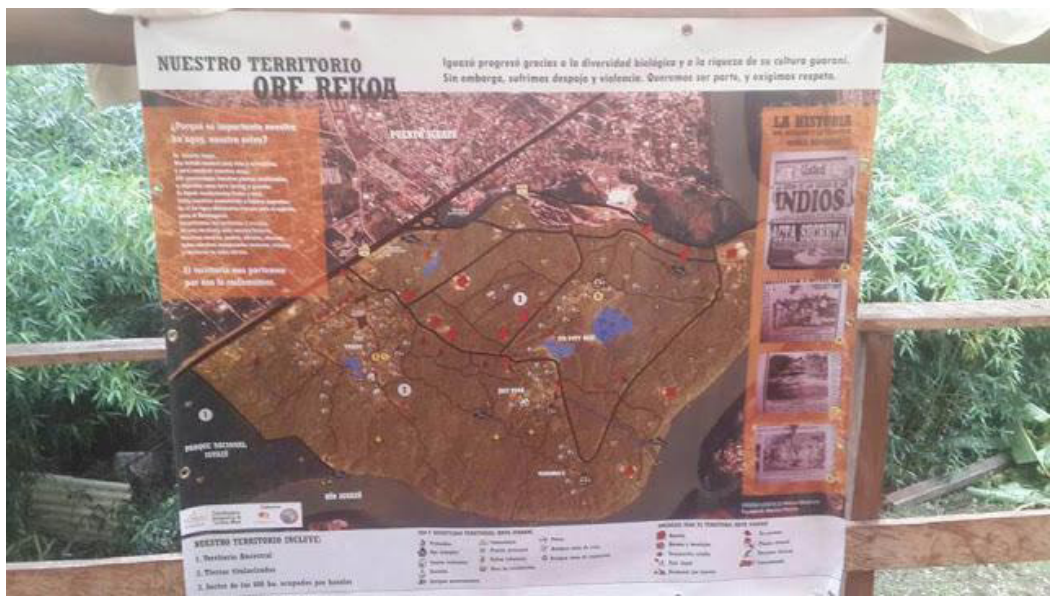

Figura 8: Mapa Nuestro Territorio Ore Rekoa

Fonte: Portal digital Crónicas de la tierra sin mal, $2021^{24}$.

Resultado de iniciativa conjunta composta em 2015 pelas quatro aldeias mbiá-guaranis que vivem nos 600 bectares ${ }^{25}$ (Yryapu, Jasy Pora, Ita Poty Miri e Tupa Mbae), o mapa delineia uma perspectiva própria e um posicionamento político dos guaranis com relação a seu território, demarcando desde pontos importantes à vida das comunidades até o território ancestral. O painel foi inaugurado com a participação de líderes indígenas locais, e para a inauguração foram convidados a imprensa, o setor turístico, membros da sociedade civil e do governo ${ }^{26}$.

Na parte superior do mapa, ao lado do título (Nuestro Territorio Ore Rekoa) estão as frases "Iguazú progresó gracias a la diversidad biológica y a la riqueza de su cultura guarani. Sin embargo, sufrimos despojo y violencia. Queremos ser parte y exigimos respeto", afirmando ao governo e à sociedade locais a participação indígena na formação da cidade e a ciência da contribuição da riqueza cultural guarani à atividade econômica do turismo. A coluna da direita do painel, intitulada "La Historia", é ilustrada por publicações antigas que situam historicamente a violência sofrida pelos indígenas em Misiones.

23. Ao final de 2019, o mural encontrava-se em mau estado e não estava mais visível, por encontrar-se em área aberta e exposto às condições climáticas locais. Infere-se que as comunidades não dispõem de recursos para sua manutenção.

24.Disponível em: < http://cronicasinmal.blogspot.com/2017/05/mapa-ore-rekoa.html > . Acesso em 28 mai. 2021.

25. O trabalho foi mediado também por agentes de organizações sociais e ONGs que têm desenvolvido formações e suporte para implementação de turismo comunitário e sustentável. Neste trabalho, por limitação de espaço, não trataremos desse aspecto.

26. A programação do evento e outras informações podem ser encontradas em: < http://cronicasinmal.blogspot.com/2017/05/mapa-ore-rekoa. html >. Acesso em 28 mai. 2021. 
Na parte inferior do mapa encontra-se uma legenda dividida em três partes, onde se lê à esquerda: "Nuestro territorio incluye: 1) Tierra ancestral, 2) Tierras titularizadas, 3) Sector de las 600 ba ocupados por boteles". A segunda parte da legenda inferior se intitula "Uso y significado territorial mbya guarani", indicando símbolos para a localização de antigos lugares de caça e pesca, os opy (casas de reza), as casas, o cemitério, uma escola e os centros de visitantes. Já a terceira parte da legenda corresponde a "Amenazas para el territorio mbya guarani", que indicam no mapa áreas ocupadas por hotéis, onde ocorre corte ilegal de madeiras, derramamento de esgoto, contrabando e queima de áreas indígenas, dentre outros.

Desse modo, indo além dos mapas oficiais e institucionais, os limites territoriais expressos marcam o esforço de construção de uma territorialidade própria, ou, melhor dizendo, a reafirmação de uma territorialidade que há muito lhes é própria, já que o povo mbiá-guarani sempre habitou o território onde hoje se encontra o empreendimento 600 bectares. Já a indicação, como ameaças para o território mbiá-guarani, de elementos como os próprios hotéis, o esgoto produzido por eles, o corte ilegal de madeiras, etc., aponta a necessidade de reterritorialização da Selva Iryapú enquanto espaço que responda às formas de vida guaranis. Conforme dito anteriormente, o território é elemento central na vida dos guaranis, e a reivindicação por sua recuperação tem sido constante, já que a falta da floresta gera problemas alimentares, dificulta ou impossibilita as práticas religiosas, inviabiliza a subsistência e enfraquece culturalmente as comunidades, além das consequências trazidas para a saúde por conta do abandono de sua medicina tradicional. Essa grave situação, causada pelo não cumprimento oficial dos direitos indígenas, tem condenado muitos guaranis a viver em situação de mendicância nas periferias de várias cidades.

Assim, da perspectiva dos letramentos de reexistência, o mapa Nuestro Territorio Ore Rekoa mostra uma apropriação das comunidades locais para comunicar outros significados e visões de sua história, sua cultura, sua identidade e do próprio território onde vivem. No caso da performance dos coros turísticos, as estratégias de reposicionamento de aspectos da cultura e religião guaranis mostram uma apropriação e adaptação em função da preservação de seus rituais tradicionais. Os dois exemplos representam formas de resistir e reexistir dessas comunidades no atual contexto de exploração turística em que estão inseridos.

A despeito da participação das comunidades indígenas no mercado turístico na Selva Iryapú e de seus discursos de resistência, ao realizar uma avaliação mais ampla, conclui-se que os investimentos turísticos transnacionais não impactaram positivamente o município de Puerto Iguazú, trazendo os prometidos benefícios à população, especialmente às comunidades indígenas (GONZÁLES et al., 2017). Como apontam Wilde (2007) e Gonzáles et al. (2017), o governo de Misiones teve um papel determinante na distribuição e no uso de terras dos 600 hectares, consoante com a tendência de muitos governos estatais de apoiar e sustentar políticas econômicas globais e neoliberais (HARVEY, 2016). Infere-se a partir daí uma subordinação de setores governamentais às grandes empresas turísticas, submetendo questões econômicas, sociais e territoriais às necessidades do mercado, e ignorando as históricas demandas do município, legitimando desse modo os discursos de lucro.

Para muitos grupos minorizados, a única oportunidade de acessar o mercado global é recriar-se e capitalizar seus potenciais culturais em potenciais turísticos. As comunidades indígenas da Selva Iryapú têm sido, assim, obrigadas a reinventar a si mesmas por meio da economia dos serviços de turismo, utilizando sua língua e cultura como recursos para gerar valor agregado à atividade turística, deslocando elementos da vida cotidiana para o campo da atividade capitalista.

Em diversos estudos sobre mercantilização da linguagem envolvendo comunidades indígenas ou minorizadas (PIETIKÄINEN et al., 2016; JAFFE, 2019; PIETIKÄINEN; KELLY-HOLMES, 2011; KELLY-HOLMES; PIETIKÄINEN, 2014), aponta-se que a abertura para a mercantilização da autenticidade e das línguas-culturas têm criado espaços para a ocorrência de processos emancipatórios protagonizados pelos sujeitos envolvidos, supostos detentores dessa autenticidade, bem como trazido oportunidades de geração de renda no nível local. Em muitos desses casos, o grupo étnico ou originário, detentor da autenticidade, busca por opção própria inserir-se no mercado turístico. Geralmente, esse processo começa ou é reforçado via políticas públicas de reconhecimento cultural e linguístico. Esse, no entanto, não é o caso dos guaranis da Selva Iryapú e da província de Misiones, que não gozam de políticas públicas efetivas que assegurem seus direitos. Ou seja, o ingresso no terceiro setor da atividade capitalista, embora gere importante fonte de renda para algumas comunidades, não é exatamente uma escolha, mas uma consequência da ausência de opções diante de um cenário de espoliação de territórios com o aval do Estado e da falta de políticas que assegurem formas de vida mais adequadas a esse povo.

Observamos, no mapa Nuestro Territorio Ore Rekoa e na performance dos coros indígenas, discursos de resistência e de reexistência das comunidades locais, uma busca de maior agentividade no mercado turístico da área. No entanto, 
conforme destacamos anteriormente, um dos grandes abismos da Selva Iryapú é a desigualdade no acesso aos recursos gerados pelo mercado turístico, relacionado a quem tem ou não legitimação para tomar decisões sobre como gerar e gerenciar os lucros dele advindos, nesse caso, as redes hoteleiras instaladas. Os mbiá-guaranis, apesar de serem detentores da autenticidade da cultura percebida e nomeada como recurso (e serem historicamente os habitantes e donos do território natural explorado pelos hotéis), não têm poder de decisão sobre o território ou sobre as condições econômicas, políticas e territoriais que garantam sua subsistência na área (CANTORE; BOFFELLI, 2017). Diante do exposto, argumentamos que, longe de tratar-se de um processo de mercantilização da autenticidade que se origina pelas demandas dos sujeitos e potencializa sua agentividade, o que se observa é um projeto de exploração capitalista que posiciona os mbiá-guaranis entre a necessidade e a resistência-reexistência.

\section{CONSIDERAÇÕES FINAIS}

Este trabalho buscou traçar um panorama inicial de usos da linguagem pelo turismo na Selva Iryapú com base no aporte teórico que congrega Sociolinguística e turismo (HELLER $;$ JAWORSKI; THURLOW, 2014) e nos entendimentos sobre mercantilização da linguagem, discutindo alguns usos da linguagem para a promoção do turismo na área, onde elementos percebidos e identificados com a língua e a cultura guaranis são mobilizados para produzir autenticidade e gerar valor agregado simbólico (HELLER; McELHINNY, 2017).

Para compreender o ingresso das comunidades guaranis da Selva Iryapú no terceiro setor, foi necessário situá-lo no âmbito da nova economia globalizada e do capitalismo tardio. Dois eixos sobressaem: por um lado, a expropriação dos territórios indígenas com o aval do Estado argentino e, consequentemente, a inviabilização da subsistência e do modo de vida dos guaranis; por outro, a alienação das comunidades indígenas dos lucros obtidos pelo setor hoteleiro a partir da exploração do território e do imaginário guarani, e a consequente privação de modos de vida dignos para essa população. Embora diversos estudos da área apontem a mercantilização da linguagem como possível potencializadora da agentividade dos sujeitos e de geração de renda a grupos minoritários, no presente caso argumentamos que os guaranis, inseridos em uma relação de exploração e alienação capitalista com o empreendimento Selva Iryapú, posicionam-se entre a necessidade e a resistência. $\mathrm{O}$ aprofundamento dessa compreensão requer futuras pesquisas que analisem outros elementos do plano macroeconômico em jogo, as complexas relações entre os discursos de orgulho e lucro, bem como as situações em que elementos de linguagem são negociados e reinventados nas dinâmicas presentes na atividade do turismo e na economia política relacionadas a esse território e às comunidades que aí vivem.

\section{REFERÊNCIAS}

APPADURAI, A. (1986). A vida social das coisas: as mercadorias sob uma perspectiva cultural. Niterói: EDUFF, 2008.

CANTORE, A.; BOFFELli, C. (2017). Etnicidad mbyá en Puerto Iguazú: Explotación turística de/en comunidades indígenas en la triple frontera (Misiones, Argentina). Runa, v. 38, n. 2, p. 53-69.

DIECKOW, L. (2012). El uso de las fallas del mercado en los productos turísticos de destinos emergentes. Estudio de caso: destino Iguazú Cataratas (Argentina-Brasil). Palermo Business Review, v. 6, p. 163-176.

ENRIZ, N. (2011). Políticas públicas para familias indígenas en Misiones. Runa, n. 32, v. 1, p. 27-42.

ENRIZ, N. (2018). Turismo internacional de gran escala e identidad étnica en la Triple Frontera misionera. Etnografías, DOSSIER 20 años del Idaes - Investigación y docencia en Ciencias Sociales para una sociedad más justa, a. 4, p. 81-88.

FIORIN, J. L.; PETTER, M. (2008). Prefácio. In: Fiorin, J. L.; Petter, M. (Orgs.), África no Brasil: a formação da língua portuguesa. São Paulo: Contexto, p. 7-11.

GIL, A. C. (2008). Métodos e técnicas de pesquisa social. São Paulo: Atlas.

GONZÁLES, R.; RAMPELLO, P.; DOMÍNGUEZ, I. (2017). Impactos socio-territoriales: Puerto Iguazú y Reserva Iriapú, 600 hectáreas. Misiones, Argentina. Revista El periplo sustentable, n. 3, p. 363-393. 
HARVEY, D. (2016). 17 contradições e o fim do capitalismo. São Paulo: Boitempo.

HARVEY, D. (2018). Alienation. Triple C, n. 16, v. 2, p. 424-439.

HELLER, M. (2005). Language, skill and authenticity in the globalized new economy. Noves SL. Revista de Sociolinguística, n. 2, p. $1-7$.

HELLER, M. (2010). The Commodification of Language. The Annual Review of Antbropology, v. 39, p. 101-114.

HELLER, M.; DUCHÊNE, A. (2012). Pride and profit: Changing discourses of language, capital and nation-state. In: Duchêne, A.; Heller, M. (orgs.), Language in late capitalism: Pride and profit. New York: Routledge, p. 1-21.

HELLER, M.; DUCHÊNE, A. (2016). Treating language as an economic resource: Discourse, data and debate. In: Coupland, N. (org.), Sociolinguistics: Theoretical debates. Cambridge: Cambridge Press, p. 139-156.

HELLER, M.; JAWORSKI, A.; THURLOW, C. (2014). Introduction: Sociolinguistics and tourism - mobilities, markets, multilingualism. Journal of Sociolinguistics, n. 18, v. 4, p. 425-458

HELLER, M.; McELHINNY, B. (2017). Language, capitalism, colonialism: toward a critical bistory. Toronto: University of Toronto Press

HELLER, M.; PUJOLAR, J.; DUCHÊNE, A. (2014). Linguistic commodification in tourism. Journal of Sociolinguistics, n. 18, v. 4, p. 539-566.

HERNÁNDEZ, F. M. (2017). "El mundo es ancho y turístico". Apuntes teórico-metodológicos para una geografía del turismo en la actualidad. Espacio y Desarrollo, n. 29, p. 57-90.

JAFFE, A. (2019). Poeticizing the economy: The corsican language in a nexus of pride and profit. Multilingua, n. 38, v. 1, p. 9-27.

KELLY-HOLMES, H.; PIETIKÄINEN, S. (2014). Commodifying Sámi culture in an indigenous tourism site. Journal of Sociolinguistics, n. 18, v. 4, p. 518-538.

MASON, J. (2002). Qualitative researching. Londres: Sage Publications.

MELIÀ, B. (1989). La tierra-sin-mal de los Guaraníes: Economía y profecía. América Indígena, n. 3, v. XLIX, p. 491 -507.

MELIÀ, B. (2008). (Org.) Guarani Retã 2008. Povos Guarani na fronteira Argentina, Brasil e Paraguai. Realização: UNaM, ENDEPA; CTI, CIMI, ISA, UFGD; CEPAG, CONAPI, SAI, GAT, SPSAJ, CAPI.

MELIÀ, B. (2016). (Org.) Mapa Guaraní Continental 2016. Povos Guarani na Argentina, Bolívia, Brasil e Paraguai. Argentina: ENDEPA e UNSA; Bolívia: APG, CIPCA, CERDET y ILC; Brasil: ATY GUASU, YVY RUPA, CIMI, CTI, ISA, FAIND, UNILA y FUNAI; Paraguai: CONAPI, Continental: CCNAGUA.

PIETIKÄINEN, S; KELLY-HOLMES, H. (2011). The local political economy of languages in a Sámi tourism destination: Authenticity and mobility in the labelling of souvenirs. Journal of Sociolinguistics, n. 15, v. 3, p. 323-346.

PIETIKÄINEN, S.; KELLY-HOLMES, H.; JAFFE, A.; COUPLAND, N. (2016). Sociolinguistics from the periphery: small languages in new circumstances. Cambridge: University Press.

SOUZA, A. L. (2011). Letramentos de reexistência-poesia, grafite, música, dança: bip-bop. São Paulo: Parábola Editorial.

SOUZA, A. L.; JOVINO, I. S.; MUNIZ, K. S. (2018). Letramento de reexistência - Um conceito em movimentos negros. Revista da ABPN, v. 10, p. 01-11.

THURLOW, C.; JAWORSKI, A. (2012). Elite mobilities: The semiotic landscapes of luxury and privilege. Social Semiotics, n. 4, v. 22, p. 487-516 
WILDE, G. (2007). De la depredación a la conservación. Génesis y evolución del discurso hegemónico sobre la selva misionera y sus habitantes. Ambiente \& Sociedade, n. 1, v. X, p. 87-106.

Recebido: $1 / 3 / 2021$

Aceito: $1 / 6 / 2021$

Publicado: 7/6/2021 